\title{
Suppression of plasminogen activator production in sheep embryos in vitro after treatment with cycloheximide or ouabain
}

\author{
A. R. Menino, Jr and J. S. Williams \\ Department of Animal Sciences, Oregon State University, Corvallis, OR 97331-6702, USA
}

\begin{abstract}
Effects of the metabolic inhibitors cycloheximide and ouabain on development in vitro and plasminogen activator production by sheep embryos were investigated. Embryos $(n=152)$ from the eight-cell to the morula stage were surgically collected from naturally mated, oestrus-synchronized and superovulated Polypay ewes. In Expt 1, embryos $(n=104)$ were grouped by cell stage, cultured in Whitten's medium with $1.5 \%$ BSA containing $0,0.1$ or $1.0 \mu \mathrm{g}$ cycloheximide $\mathrm{ml}^{-1}$ for $24 \mathrm{~h}$, washed and cultured in this medium for $168 \mathrm{~h}$. In Expt 2, morulae $(n=48)$ were cultured for $48 \mathrm{~h}$ in Whitten's medium with $1.5 \%$ BSA transferred to the same medium containing 0 or $1.0 \mathrm{mmol}$ ouabain $\mathrm{l}^{-1}$ and cultured for $24 \mathrm{~h}$, and then washed and cultured in this medium for $120 \mathrm{~h}$. At $24 \mathrm{~h}$ intervals in both experiments, the medium was recovered and analysed for plasminogen activator. In Expt 1 , eight-cell embryos underwent limited development; little difference in the production of plasminogen activator due to cycloheximide treatment was therefore observed. Compared with medium without cycloheximide, treatment with $1.0 \mu \mathrm{g}$ cycloheximide $\mathrm{ml}^{-1}$ reduced the number of 16 -cell embryos $(P<0.05)$ and morulae $(P<0.05)(60 \%$ versus $10 \%$ and $77 \%$ versus $8 \%$, respectively) that began to hatch. The mean production of plasminogen activator was greatest in embryos cultured initially as morulae compared with that of 16-cell and eight-cell embryos $(P<0.05)$. Cycloheximide treatment suppressed the mean production of plasminogen activator in a dose-dependent manner $(P<0.05)$. In Expt 2, fewer embryos $(P<0.05)$ developed to the blastocyst and expanded blastocyst stages following ouabain treatment $(83 \%$ and $4 \%$, respectively) compared with embryos not exposed to ouabain (100\% and $100 \%$, respectively). Embryos treated with ouabain produced less plasminogen activator than did untreated embryos $(P<0.05)$. These results suggest that developmental changes caused by treating sheep embryos with cycloheximide or ouabain are reflected by changes in the production of plasminogen activator.
\end{abstract}

\section{Introduction}

Embryos of several species, including rats (Liedholm and Astedt, 1975), mice (Strickland et al., 1976), pigs (Mullins et al., 1980), cattle (Menino and Williams, 1987) and sheep (Menino et al., 1989), produce the serine protease plasminogen activator (PA). Tissue-type PA (tPA) is first detected during meiotic maturation in rat and mouse oocytes, but its concentration diminishes during fertilization (Huarte et al., 1985). In mouse oocytes, mRNA encoding tPA is a stored maternal transcript that is polyadenylated, translated and rapidly degraded (Huarte et al., 1987; Strickland et al., 1988; Vassalli et al., 1989). With the exception of rat embryos (Liedholm and Astedt, 1975), PA activity is not detected again until the morula-blastocyst transition in sheep (Menino et al., 1989) or the blastocyst stage in mice (Strickland et al., 1976), pigs (Fazleabas et al., 1983) or cattle (Menino and Williams, 1987). The pattern of PA production by mouse, pig and, to some extent, bovine

Revised manuscript received 17 January 1994. embryos, is biphasic and correlated with certain developmental events. For example, in mouse embryos, the first phase corresponds to trophoblastic invasion of the endometrium, while the second phase coincides with parietal endodermal cell migration and expansion of trophoblast giant cells (Strickland et al., 1976; Strickland, 1980; Sappino et al., 1989).

Despite this information, little attention has been focused on factors that regulate the expression of PA during early embryo development. Our laboratory has recently demonstrated that the pattern of PA production by 8-day-old cattle embryos cultured for 5 days cannot be modified by a variety of steroid hormones, retinoic acid or stimulators of the protein kinase $\mathrm{A}$ and C systems (Al-Hozab and Menino, 1992). These data suggest that early embryonic PA production is intrinsically regulated and that expression may be linked to temporal molecular mechanisms occurring within the embryo (Satoh, 1982). In sheep embryos, transcriptional and translational events necessary for PA production may be occurring when the embryonic genome is activated during the 8-16-cell stage (Crosby et al., 1988). Exposing sheep embryos to either a 
transcriptional or translational inhibitor during a specific cell stage should allow identification of the stage when the molecular events critical to PA production are occurring. This was the approach used by Kidder and McLachlin (1985) to determine when the necessary transcriptional and translational events for compaction, cavitation and hatching were occurring in mouse embryos.

Because PA activity increases during the morula-blastocyst transition and blastocoelic expansion in sheep embryos (Menino et al., 1989), there may be a relationship between cavitation and PA production. Some evidence for such a potential interaction is provided by Finotti and Verbaro (1987), who have identified serum proteases that can stimulate the $\mathrm{Na}^{+}-\mathrm{K}^{+}$ATPase. The $\mathrm{Na}^{+}-\mathrm{K}^{+}$ATPase is expressed in the trophectoderm and is integral for blastulation and blastocoelic expansion (see review by Watson, 1992). The cardiac glycoside ouabain has been known to be an inhibitor of the $\mathrm{Na}^{+}-\mathrm{K}^{+}$ ATPase and cavitation (Smith, 1970). If there is a relationship between cavitation and PA production, then suppressing blastocoelic expansion with ouabain may cause concomitant changes in PA activity. The objectives of this study were therefore (I) to identify the cell stages in which treatment with the protein synthesis inhibitor cycloheximide reduces subsequent PA production, and (2) to determine whether suppression of blastocoelic expansion with ouabain, an inhibitor of $\mathrm{Na}^{+}-\mathrm{K}^{+}$ATPase, affects PA output by sheep embryos in vitro.

\section{Materials and Methods}

\section{Animals}

Twenty-seven Polypay ewes from the Oregon State University Sheep Center, Corvallis were treated with cloprostenol sodium (Estrumate: Haver, Shawnee, KS) to synchronize oestrus and with porcine FSH ( $\mathrm{pFSH}$; Schering Corporation, Kenilworth, NJ) to induce superovulation. As part of an ongoing project in our laboratory to evaluate oestrous synchronization and superovulation treatments for sheep, ewes in Expts 1 and 2 (see below) were oestrus-synchronized and superovulated twice using two different regimens. Embryos were collected surgically after each round of oestrus synchronization and superovulation. In Expt 1, two $100 \mu \mathrm{g}$ injections of Estrumate were administered i.m. 10 days apart to 16 ewes (day 0, first Estrumate injection), while pFSH injections were administered twice a day i.m. at dosages of 5,4 and $3 \mathrm{mg}$ on days 9,10 and 11 , respectively (treatment 1 ). Approximately 60 days later, two $100 \mu \mathrm{g}$ injections of Estrumate were administered i.m. 8 days apart, and pFSH injections were administered twice a day i.m. at dosages of 4,3 and $2 \mathrm{mg}$ on days 7, 8 and 9, respectively (treatment 2). In Expt 2, 11 ewes were oestrus-synchronized and superovulated initially with treatment 2 and approximately 60 days later with treatment 1 . In both experiments, the ewes were monitored for oestrus $24 \mathrm{~h}$ after the second Estrumate injection. Ewes were mated to one of four rams at the onset of oestrus and every $12 \mathrm{~h}$ thereafter for either as long as the ewe would accept a ram or for a total of four matings.

\section{Embryo collection}

Embryos were collected from ewes 4-6 days after the onset of oestrus in Expt 1 and 5-6 days after the onset of oestrus in Expt 2. Ewes were deprived of food and water for 36 and $24 \mathrm{~h}$, respectively, before surgical collection of embryos. Anaesthesia was induced in ewes by injecting i.v. $15-20 \mathrm{ml}$ of $2.5 \%$ thiamylal sodium (Biotal; Boehringer Ingelheim Animal Health, Inc., St Joseph, $\mathrm{MO}$ ) and was maintained during surgery by allowing the ewes to inhale halothane (Fluothane: Fort Dodge Laboratories, Inc., Fort Dodge, IA) and oxygen. The reproductive tract was exteriorized via ventral midline laparotomy and the oviducts and uteri were flushed in retrograde fashion with Whitten's medium (Whitten and Biggers, 1968) buffered with $25 \mathrm{mmol}$ Hepes $\mathrm{I}^{-1}$ (Sigma Chemical Co., St Louis, MO) but lacking BSA.

Flushings were examined under a dissecting microscope at a magnification of $\times 10-20$, and ova (including unfertilized oocytes and embryos) were recovered by aspiration. Ova were washed in Hepes-buffered Whitten's medium supplemented with $1.5 \%$ BSA (Sigma Chemical Co.) (WM) and transported to the laboratory in screw-cap tissue culture tubes containing $5 \mathrm{ml}$ of this medium at $37^{\circ} \mathrm{C}$. Ova were recovered from the tubes, washed in $50 \mu \mathrm{l}$ drops of WM under paraffin oil (Fisher Scientific Co., Tustin, CA) and their morphology was studied with an inverted-stage, phase-contrast microscope at a magnification of $\times 100-200$. The total numbers of ova, embryos and morphologically normal embryos recovered were 244, 166 and 152, respectively. Oestrus synchronization and superovulation treatment did not significantly affect the mean numbers of morphologically normal embryos collected.

\section{Embryo culture}

In Expts 1 and 2 embryos were cultured in $50 \mu$ drops (3-5 embryos per drop) under a humidified atmosphere of $5 \%$ $\mathrm{CO}_{2}$ in air at $37^{\circ} \mathrm{C}$, and were observed daily for the stage of development reached (Wright et al., 1976). At $24 \mathrm{~h}$ intervals, starting after $24 \mathrm{~h}$ of culture and continuing up to $192 \mathrm{~h}$ of culture, embryos were transferred to fresh drops and the medium was recovered and frozen at $-20^{\circ} \mathrm{C}$ until assayed for PA. Medium from drops not containing embryos was also recovered to correct for any spontaneous activation of plasminogen in the PA assay.

\section{Experiment 1}

Eight-cell and 16-cell embryos and morulae $(n=104)$ were grouped by cell stage and cultured immediately in WM containing $0,0.1$ or $1.0 \mu \mathrm{g}$ cycloheximide $\mathrm{ml}^{-1}$ (Sigma Chemical Co.) for $24 \mathrm{~h}$. Embryos were recovered from the drops, washed three times and cultured for $168 \mathrm{~h}$ in WM.

\section{Experiment 2}

Morulae $(n=48)$ were initially cultured for $48 \mathrm{~h}$ in WM, transferred to WM containing 0 or $1.0 \mathrm{mmol}$ ouabain $1^{-1}$ (Sigma Chemical Co.) for $24 \mathrm{~h}$, washed three times and cultured in WM for $120 \mathrm{~h}$. 


\section{Plasminogen activator assay}

Plasminogen activator concentrations in the culture medium were determined using a caseinolytic assay, as described by Menino et al. (1989) for sheep embryos. Urokinase (E.C. 3.4.21.31; Sigma Chemical Co.) was used as the standard at concentrations of $0,0.1,0.5,1.0,5.0$ and $10.0 \mathrm{mU} \mathrm{ml}^{-1}$, and porcine plasminogen (Sigma Chemical Co.) was used as the substrate. Because embryos were evaluated at $24 \mathrm{~h}$ intervals and scored for stage of development and evidence of degeneration, PA activity is expressed as $\mathrm{mU} \mathrm{PA} \times 10^{-4} \mathrm{ml}^{-1} \mathrm{~h}^{-1}$ per viable embryo.

\section{Statistical analyses}

Differences between treatments in the percentages of embryos developing to a particular cell stage were analysed by chi-squared test. In Expt I, three-way analysis of variance (ANOVA) and orthogonal contrasts were used to evaluate the effects of initial cell stage, concentration of cycloheximide, time in culture and of corresponding interactions on PA production. Two-way ANOVA and Fisher's Isd were used to evaluate the effects of initial cell stage and cycloheximide on the time taken to develop to the blastocyst and hatching blastocyst stages. In Expt 2, two-way ANOVA and orthogonal contrasts were used to evaluate the effects of ouabain and time in culture on PA production.

\section{Results}

\section{Experiment 1}

For eight-cell embryos exposed to $0,0.1$ or $1.0 \mu \mathrm{g}$ cycloheximide $\mathrm{ml}^{-1}, 5$ of $11(45 \%), 3$ of $9(33 \%)$ and 3 of $12(25 \%)$ developed into morulae, respectively. Development to the blastocyst stage was limited and observed in only 2 of 11 embryos (18\%) incubated in WM without cycloheximide (Fig. 1a). Eight-cell embryos did not develop beyond the blastocyst stage. Blastocyst formation occurred in 9 of 10 $(90 \%), 9$ of $12(75 \%)$ and 4 of $10(40 \%)$ 16-cell embryos incubated in WM with $0,0.1$ or $1.0 \mu \mathrm{g}$ cycloheximide $\mathrm{ml}^{-1}$, respectively (Fig. 1a). Culture with $1.0 \mu \mathrm{g}$ cycloheximide $\mathrm{ml}^{-1}$ reduced $(P<0.05)$ the number of 16-cell embryos that developed into blastocysts compared with the number cultured without cycloheximide. The number of 16-cell embryos that developed into blastocysts and initiated hatching, by producing a crack or rent in the zona pellucida, or that completely escaped from the zona pellucida after exposure to $0,0.1$ or $1.0 \mu \mathrm{g}$ cycloheximide $\mathrm{ml}^{-1}$ were 6 of $10(60 \%), 4$ of $12(33 \%)$ and 1 of $10(10 \%)$, respectively (Fig. Ib). More $(P<0.05)$ 16-cell embryos developed into blastocysts that initiated the hatching process after incubation without cycloheximide than with $1.0 \mu \mathrm{g}$ cycloheximide $\mathrm{ml}^{-1}$. Blastocyst formation (Fig. 1a) was reduced but did not differ $(P>0.05)$ in morulae cultured in WM with 0.1 (11 of $14 ; 79 \%$ ) or 1.0 (10 of $13 ; 77 \%$ ) $\mu \mathrm{g}$ cycloheximide $\mathrm{ml}^{-1}$ compared with morulae cultured in WM without cycloheximide (13 of $13 ; 100 \%$ ). The number of morulae that developed into blastocysts and initiated hatching was greater $(P<0.05)$ after incubation in WM without cycloheximide (10 of $13 ; 77 \%$ ) than in 0.1 ( 5 of $14 ; 36 \%$ ) or 1.0 ( 1 of

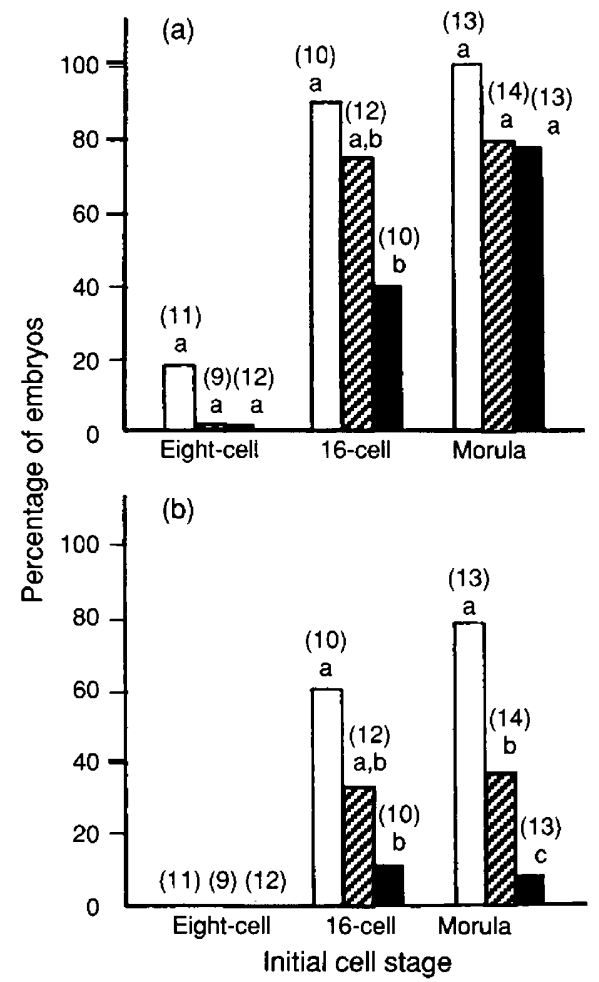

Fig. 1. Percentages of sheep embryos developing to (a) the blastocyst stage and (b) the hatching stage following exposure to $(\square) 0,(\square) 0.1$ or (D) $1.0 \mu \mathrm{g}$ cycloheximide $\mathrm{ml}^{-1}$ at the eight-cell, 16-cell or morula stages. The number of embryos cultured is given in parentheses. Values with different letters are significantly different $(P<0.05)$.

13; $8 \%$ ) $\mu$ g cycloheximide $\mathrm{ml}^{-1}$ (Fig. 1b). More $(P<0.05)$ morulae developed into blastocysts that initiated hatching after exposure to $0.1 \mu \mathrm{g}$ cycloheximide $\mathrm{ml}^{-1}$ than those exposed to $1.0 \mu \mathrm{g}$ cycloheximide $\mathrm{ml}^{-1}$. Development to the blastocyst and hatching blastocyst stages by 16-cell embryos and morulae was delayed owing to cycloheximide treatment; however, significant differences $(P<0.05)$ were observed only for morulae (Table 1). Morulae typically developed into blastocysts and hatched sooner $(P<0.05)$ than did 16-cell embryos, and no significant interactions $(P>0.10)$ between initial cell stage and cycloheximide concentration were observed.

Initial cell stage, cycloheximide concentration and time in culture affected $(P<0.05)$ PA production by sheep embryos (Fig. 2). The interactions between initial cell stage and cycloheximide concentration, and initial cell stage and time in culture were also significant $(P<0.05)$. During the $192 \mathrm{~h}$ in culture eight-cell embryos produced less $(P<0.01)$ mean PA $\left(0.6 \pm 0.5 \times 10^{-4} \mathrm{mU} \mathrm{ml}^{-1} \mathrm{~h}^{-1}\right.$ per embryo) than did either 16-cell embryos (2.I $\pm 0.5 \times 10^{-4} \mathrm{mU} \mathrm{ml}^{-1} \mathrm{~h}^{-1}$ per embryo) or morulae $\left(4.0 \pm 0.5 \times 10^{-4} \mathrm{mU} \mathrm{ml}^{-1} \mathrm{~h}^{-1}\right.$ per embryo). Exposure to $0,0.1$ and $1.0 \mu \mathrm{g}$ cycloheximide $\mathrm{ml}^{-1}$ for $24 \mathrm{~h}$ suppressed $(P<0.01)$ subsequent mean $\mathrm{PA}$ production by 16-cell embryos $\left(3.5 \pm 0.5,2.1 \pm 0.5\right.$ and $0.9 \pm 0.5 \times 10^{-4} \mathrm{mU}$ $\mathrm{ml}^{-1} \mathrm{~h}^{-1}$ per embryo, respectively) and morulae (7.3 \pm 1.3 , $3.2 \pm 1.3$ and $1.6 \pm 1.3 \times 10^{-4} \mathrm{mU} \mathrm{ml}^{-1} \mathrm{~h}^{-1}$ per embryo, respectively) in a dose-dependent fashion, but no such effect $(P>0.05)$ was observed in eight-cell embryos (0.4 \pm 0.1 , 
Table 1. Time to the blastocyst and hatching blastocyst stages for sheep 16-cell embryos and morulae cultured for $24 \mathrm{~h}$ in medium containing $0,0.1$ or $1.0 \mu \mathrm{g}$ cycloheximide $\mathrm{ml}^{-1}$

\begin{tabular}{lccccccc}
\hline Initial cell stage & $\begin{array}{c}\text { Cycloheximide } \\
\left(\mu \mathrm{g} \mathrm{ml}^{-1}\right)\end{array}$ & \multicolumn{3}{c}{ Time to blastocyst stage (h) } & \multicolumn{3}{c}{ Time to hatching blastocyst stage (h) } \\
SEM
\end{tabular}

Values presented are arithmetic means. SEM is the pooled standard error of the mean computed from the error mean square.

*Value is significantly different from untreated morulae $(P<0.05)$.

$0.7 \pm 0.1$ and $0.7 \pm 0.1 \times 10^{-4} \mathrm{mU} \mathrm{ml}^{-1} \mathrm{~h}^{-1}$ per embryo, respectively). Production of PA by eight-cell embryos was greater $(P<0.05)$ after $120 \mathrm{~h}$ of culture than after 24 and $48 \mathrm{~h}$ and was greater after 72 and $96 \mathrm{~h}$ than after $24,48,144,168$ and $192 \mathrm{~h}$ of culture (Fig. 2). In 16-cell embryos, PA production was greater $(P<0.05)$ after $168 \mathrm{~h}$ of culture than after $24 \mathrm{~h}$, and was greater after $192 \mathrm{~h}$ than after $24,48,72,96,120$ and $144 \mathrm{~h}$ of culture. In morulae, PA production was greater $(P<0.05)$ after $168 \mathrm{~h}$ than after 24 and $48 \mathrm{~h}$ of culture, and was greater after $192 \mathrm{~h}$ than after $24,48,72,96,120$ and $144 \mathrm{~h}$ of culture. The interactions between initial cell stage and either cycloheximide or time in culture are due to deviations in PA production by eight-cell embryos compared with 16-cell embryos and morulae.

\section{Experiment 2}

By $48 \mathrm{~h}$ of culture, the time of ouabain treatment, 37 of $48(77 \%)$ embryos had developed to the blastocyst stage. Exposure to $1.0 \mathrm{mmol}$ ouabain $1^{-1}$ reduced $(P<0.05)$ the number of embryos developing into blastocysts and undergoing blastocoelic expansion (Fig. 3) compared with $0 \mathrm{mmol}$ ouabain $1^{-1}$ (20 of $24 ; 83 \%$ and 1 of $24 ; 4 \%$, respectively, versus 24 of $24 ; 100 \%$ and 24 of $24 ; 100 \%$ respectively). Initiation of hatching was eliminated $(P<0.05)$ in embryos exposed to $1.0 \mathrm{mmol}$ ouabain $\mathrm{l}^{-1}$ ( 0 of 24 ), whereas 17 of 24 (71\%) and 3 of 24 (12\%) embryos initiated and completed hatching, respectively, when they were not exposed to ouabain. The numbers of degenerate embryos in the two treatments were also compared to validate that the effects observed with ouabain were not due to embryo death. Although slightly greater, no difference $(P>0.05)$ was observed in the numbers of embryos that degenerated in culture following treatment with 0 ( 3 of $24 ; 12 \%$ ) or 1.0 (6 of 24; $25 \%)$ mmol ouabain $\mathrm{l}^{-1}$.

The main effects of ouabain concentration and time in culture affected $(P<0.05)$ PA production, and a significant interaction between these main effects persisted (Fig. 4). The mean PA production was reduced $(P<0.05)$ after treatment with $1.0 \mathrm{mmol}$ ouabain $\mathrm{l}^{-1}\left(1.4 \pm 0.6 \times 10^{-4} \mathrm{mU} \mathrm{ml}^{-1} \mathrm{~h}^{-1}\right.$ per embryo) compared with $0 \mathrm{mmol}$ ouabain $\mathrm{l}^{-1}$ $\left(8.6 \pm 0.6 \times 10^{-4} \mathrm{mU} \mathrm{ml}^{-1} \mathrm{~h}^{-1}\right.$ per embryo). Production of

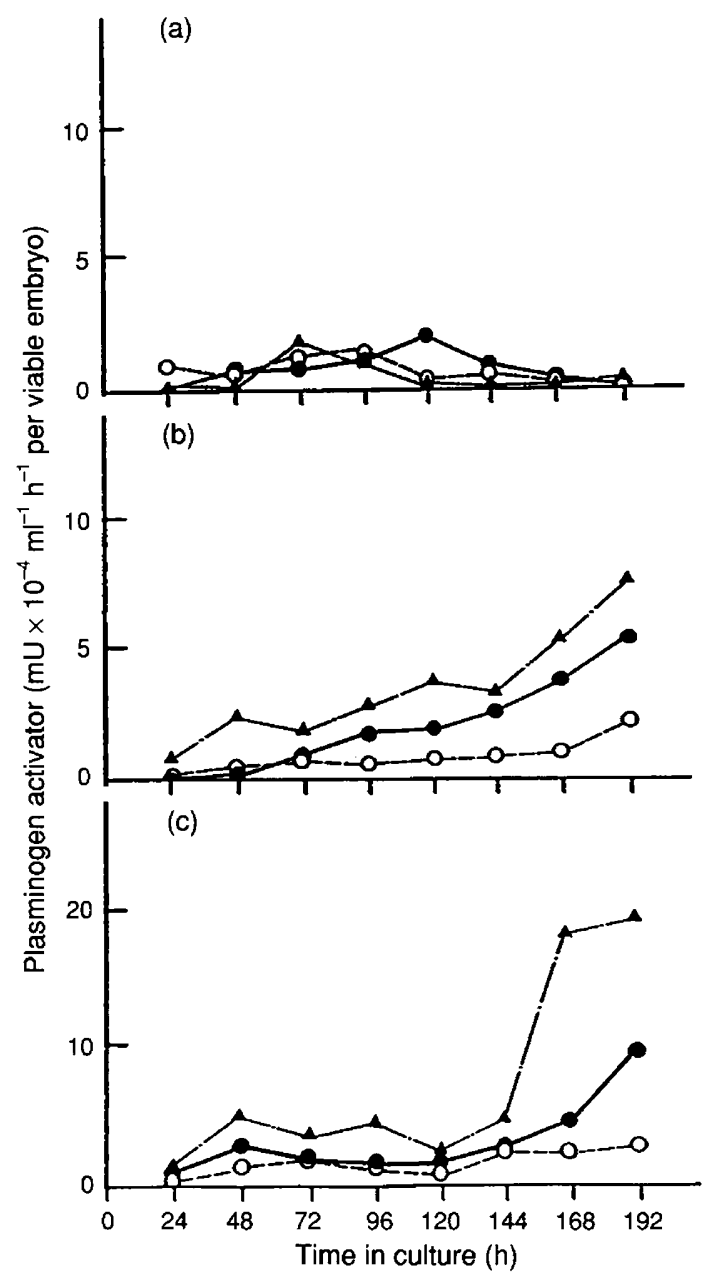

Fig. 2. Plasminogen activator $(\mathrm{PA})$ production by sheep embryos after exposure to $(\mathbf{A}) 0,(\mathbf{O}) 0.1$ or $(O) 1.0 \mu \mathrm{g}$ cycloheximide $\mathrm{ml}^{-1}$ at the (a) eight-cell, (b) 16-cell or (c) morula stages. Each point is the arithmetic mean of three replicates containing three to five embryos per replicate. Pooled SEMS for the lines describing PA production after treatment with $0,0.1$ or $1.0 \mu \mathrm{g}$ cycloheximide $\mathrm{ml}^{-1}$ are for (a) $0.3,0.4$ and 0.3 , (b) 1.4, 1.4 and 1.4 and (c) 3.6, 3.6 and 3.6, respectively.

PA by embryos that were not treated with ouabain progressively increased $(P<0.05)$ over time and was greater $(P<0.05)$ 


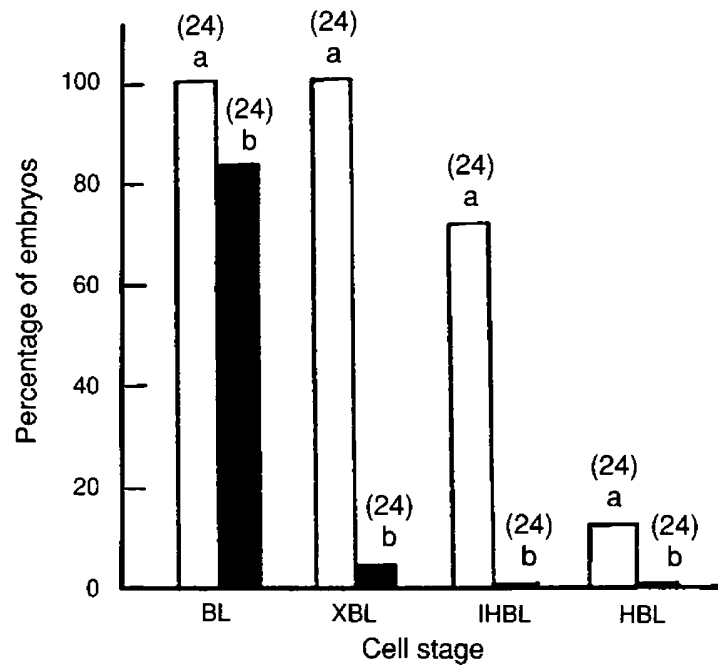

Fig. 3. Percentages of sheep monulae attaining the blastocyst (BL), expanded blastocyst (XBL), hatching blastocyst (IHBL) and hatched blastocyst (HBL) stages after incubation in ( $\square$ ) 0 or $(\square) 1.0 \mathrm{mmol}$ ouabain $\mathrm{l}^{-1}$. The number of embryos cultured is given in parentheses. Values with different letters are significantly different $(P<0.05)$.

after $192 \mathrm{~h}$ of culture than after $24,48,72$ and $96 \mathrm{~h}$ of culture (Fig. 4). However, PA production declined $(P<0.05)$ following exposure to $1.0 \mathrm{mmol}$ ouabain $1^{-1}$ and remained low throughout the culture period (Fig. 4), thereby explaining the interaction between ouabain treatment and time in culture.

\section{Discussion}

In the present study, cycloheximide treatment reduced the numbers of 16-cell embryos developing into blastocysts and hatching and the numbers of morulae developing into hatching blastocysts. In addition, exposure to cycloheximide at the morula stage significantly delayed cavitation and hatching. Although blastulation was reduced in eight-cell embryos treated with cycloheximide, the limited development undergone by these embryos makes it difficult to draw meaningful conclusions. However, these results suggest that the protein synthetic events required for blastocoel formation occur at the 16-cell stage, while those required for hatching occur throughout the 16-cell and morula stages. The reduced number of blastocysts formed by cycloheximide-treated 16-cell embryos would also be expected to contribute to the reduced incidence of hatching observed in these embryos.

Although the incidence of blastocyst formation was not significantly affected in morulae treated with cycloheximide, the onset of cavitation and hatching were delayed, suggesting that important protein synthetic events occur during the morula stage that are necessary for the proper timing of blastulation and hatching. Protein synthesis is presumably restored after removal of cycloheximide; however, if a synthetic process that is cell-stage-specific is inhibited, it is likely that the effects will be observed in later stages providing this process is critical to development. For example, when Kidder and McLachlin (1985) treated early mouse blastocysts with the transcriptional inhibitor $\alpha$-amanitin,

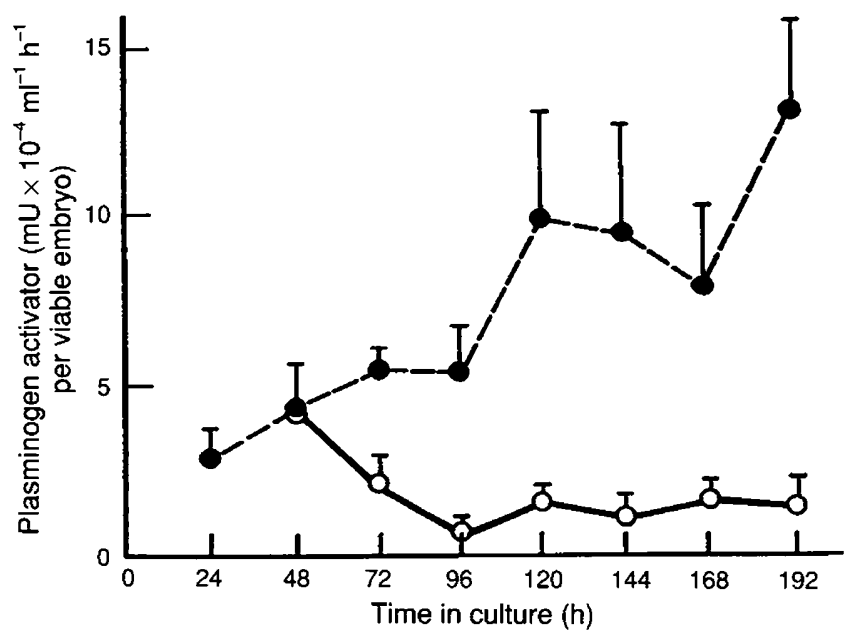

Fig. 4. Plasminogen activator (PA) production by sheep embryos following incubation in (O) 0 or (O) $1.0 \mathrm{mmol}$ ouabain $\mathrm{l}^{-1}$. Each point is the arithmetic mean of five replicates containing 4-5 embryos per replicate. Pooled SEMS for the lines describing PA production after treatment with 0 or $1.0 \mathrm{mmol}$ ouabain $1^{-1}$ are 1.4 and 1.4 , respectively.

hatching was inhibited. When blastocysts at later stages were treated with $\alpha$-amanitin, the incidence of hatching was similar to that of the controls, suggesting that the transcriptional events required for hatching occurred at the early blastocyst stage. Kidder and McLachlin (1985) also reported that blastulation and hatching were blocked by cycloheximide when mouse embryos were treated $1-3$ and 4-6h, respectively, in advance of the midpoint of the time course for these processes in the control population. They concluded that the necessary transcriptional and translational events occurred within a few hours of cavitation, whereas hatching was characterized by a long delay between transcriptional and translational events, and the necessary protein synthesis was completed a few hours before the onset (Kidder and McLachlin, 1985). Differences in the timing requirements for protein synthesis in blastulation and hatching between mouse and sheep embryos may be due to differences in the timing of activation of the embryonic genome. Mouse embryos undergo the transition from maternal to embryonic genomic control at the two-cell stage, whereas sheep embryos make the transition at the 8-16-cell stage (see reviews by Telford et al., 1990; Schultz and Heyner, 1992).

Production of PA was suppressed in a dose-dependent fashion by cycloheximide in both 16-cell embryos and morulae, suggesting that PA synthesis occurs during these stages of development. Suppressing protein synthesis for $24 \mathrm{~h}$ at the 16-cell and morula stages caused a reduction in PA production to be maintained for 8 days of culture, suggesting that another wave of PA synthesis does not occur until sometime after hatching. PA is commonly synthesized as a single-chain zymogen and the actual cellular mechanism for inducing its secretion varies with the type of cell being studied (Dano et al., 1985). Because sheep embryos are considered to undergo activation of the embryonic genome at the 8-16-cell stage, transcripts for PA may be synthesized during this period and subsequently translated at the 16-cell and morula stages. Crosby et al. (1988) have reported differences in polypeptide 
profiles between 1-4-cell embryos and embryos between the 16-cell and the early blastocyst stages in sheep. In their report, one of the major polypeptides observed in embryos between the 16-cell and early blastocyst stages not found in 1-4-cell embryos was a polypeptide in the $46-48 \mathrm{kDa}$ range. The molecular mass of the secreted sheep embryonic PA is $48-5 \mathrm{I} \mathrm{kDa}$ and is a type of urokinase (Bartlett and Menino, 1993). It is therefore quite possible that the zymogen for PA is synthesized between the 16-cell and early blastocyst stages and that secretion is regulated by a post-translational mechanism. Menino ef al. (1989) observed that the appearance of PA in the culture medium was associated with sheep embryos undergoing the morula-blastocyst transition. It may be that the secretion mechanism for PA is somehow linked to the onset of cavitation.

The similarity in the timing of the onset of PA detection in the culture medium and cavitation was the impetus for evaluating the effects of ouabain and inhibition of blastocoelic expansion on PA production. If the report by Finotti and Verbaro (1987) with respect to serine proteases that stimulate $\mathrm{Na}^{+}-\mathrm{K}^{+}$ATPase, is taken into account, a possible role for PA in early sheep embryo development may be to stimulate the $\mathrm{Na}^{+}-\mathrm{K}^{+}$ATPase and augment blastocoelic expansion. Ouabain is a well-recognized inhibitor of the $\mathrm{Na}^{+}-\mathrm{K}^{+}$ATPase and cavitation (Smith, 1970), and treatment of sheep embryos with $1.0 \mathrm{mmol}$ ouabain $\mathrm{l}^{-1}$ effectively suppressed not only blastocoelic expansion but also PA production. Blastocysts treated with ouabain collapsed and did not regain blastocoels until $72 \mathrm{~h}$ after they had been exposed to ouabain. Because the incidences of degenerating embryos were similar in medium with or without ouabain, it is unlikely that a nonspecific cytotoxic effect of ouabain caused the suppression of PA production. There are three possible explanations for the effect of ouabain on PA secretion. One possibility is that the signalling mechanism for PA secretion is linked to or coupled with cavitation. If this is the case, then blocking cavitation would limit the release of PA into the medium. Alternatively, treatment with ouabain may have shifted the balance of intracellular ions and factors involved in normal cellular regulation and secretion, thereby causing an aberrant release of PA. Lastly, ouabain treatment has been shown to inhibit, in addition to the $\mathrm{Na}^{+}-\mathrm{K}^{+}$ATPase, other energetic processes in embryos (Benos and Balaban, 1983). This could include processes necessary for PA secretion. Kaaekuahiwi and Menino (1990) established that PA production in bovine embryos is greater in embryos destined to hatch and is positively correlated with embryonic size and number of cells. Although the incidences of degenerating embryos did not differ, embryo viability with respect to cell division and other cellular functions may have been compromised; hence, PA production may have mirrored these effects.

In summary, these data suggest that in sheep embryos blastocoel formation is dependent upon protein synthesis at the 16-cell stage, whereas hatching appears to require protein synthesis during the 16-cell and morula stages. This period must also be important for PA synthesis because inhibition of protein synthesis at the 16-cell and morula stages causes a sustained reduction in PA production for 8 days of culture. Suppression of blastocoelic expansion with ouabain causes a concomitant suppression of PA production. Because the onset of PA production in sheep embryos follows a timecourse similar to cavitation, it is possible that the morphogenic event of cavitation is related to PA release. However, other effects of ouabain on cell function may have compromised embryo vitality, which then resulted in reduced PA production.

The authors thank D. Martin for typing the manuscript. Technical Paper No. 10009 , Oregon Agricultural Experiment Station.

\section{References}

Al-Hozab AA and Menino AR, Jr (1992) Lack of effect of hormones and inducers of intracellular messengers on plasminogen activator production by bovine embryos in vitro Joumal of Reproduction and Fertility $9679-90$

Bartlett SE and Menino AR, Jr (1993) Partial characterization of the plasminogen activator produced by ovine embryos in vitro Biology of Reproduction 49 381-386

Benos DJ and Balaban RS (1983) Energy metabolism of preimplantation mammalian blastocysts American journal of Physiology 245 40-45

Crosby IM, Gandolfi F and Moor RM (1988) Control of protein synthesis during early cleavage of sheep embryos Journal of Reproduction and Fertility $\mathbf{8 2}$ 769-775

Dano K, Andreasen PA, Grondahl-Hansen J, Kristensen P, Nielsen LS and Skriver L (1985) Plasminogen activators, tissue degradation and cancer Advances in Cancer Research 44 139-266

Fazleabas AT, Geisert RD, Bazer FW and Roberts RM (1983) Relationship between release of plasminogen activator and estrogen by blastocysts and secretion of plasmin inhibitor by uterine endometrium in the pregnant pig Biology of Reproduction $29225-238$

Finotti $P$ and Verbaro R (1987) Identification and partial purification of a ( $\mathrm{Na}-\mathrm{K}$ ) ATPase stimulating serine protease from plasma of insulin-dependent diabetics Clinica Chimica Acta 170 121-134

Huarte J, Belin D and Vassalli J-D (1985) Plasminogen activator in mouse and rat oocytes: induction during meiotic maturation Cell 43 551-558

Huarte J, Belin D, Vassalli A, Strickland S and Vassalli J-D (1987) Meiotic maturation of mouse oocytes triggers the translation and polyadenylation of dormant tissue-type plasminogen activator mRNA Genes and Development 1 1201-1211

Kaaekuahiwi MA and Menino AR (1990) Relationship between plasminogen activator production and bovine embryo development in vitro Journal of Animal Science 68 2009-2014

Kidder GM and McLachlin JR (1985) Timing of transcription and protein synthesis underlying morphogenesis in preimplantation mouse embryos Developmental Biology 112 265-275

Liedholm P and Astedt B (1975) Fibrinolytic activity of the rat ovum, appearance during tubal passage and disappearance at implantation International Journal of Fertility 20 24-26

Menino AR and Williams JS (1987) Activation of plasminogen by the early bovine embryo Biology of Reproduction 36 1289-1295

Menino AR, Dyk AR, Gardiner CS, Grobner MA, Kaaekuahiwi MA and Williams JS (1989) The effects of plasminogen on in vitro ovine embryo development Biology of Reproduction 41 899-905

Mullins DE, Bazer FW and Roberts RM (1980) Secretion of a progesteroneinduced inhibitor of plasminogen activator by the porcine uterus Cell $\mathbf{2 0}$ $865-872$

Sappino A-P, Huarte J, Belin D and Vassali J-D (1989) Plasminogen activators in tissue remodeling and invasion: mRNA localization in mouse ovaries and implanting embryos The Journal of Cell Biology 109 2471-2479

Satoh N (1982) Timing mechanisms in early embryonic development Differentiation 22 156-163

Schultz GA and Heyner S (1992) Gene expression in pre-implantation mammalian embryos Mutation Research 296 17-31

Smith MW (1970) Active transport in the rabbit blastocyst Experientia 26 $736-738$

Strickland S (1980) Plasminogen activator in early development. In Development in Mammals pp 81-100 Ed. MH Johnson. Elsevier/NorthHolland Biomedical Press, Amsterdam

Strickland S, Reich E and Sherman MI (1976) Plasminogen activator in early embryogenesis: enzyme production by trophoblast and parietal endoderm Cell 9 231-240 
Strickland S, Huarte J, Belin D, Vassalli A, Rickles RJ and Vassalli J-D (1988) Antisense RNA directed against the 3 ' noncoding region prevents dormant mRNA activation in mouse oocytes Science 241 680-684

Telford NA, Watson AJ and Schultz GA (1990) Transition from maternal to embryonic control in early mammalian development: a comparison of several species Molecular Reproduction and Development 26 90-100

Vassalli J-D, Huarte J, Belin D, Gubler P, Vassalli A, O'Connell ML, Parton LA, Rickles RJ and Strickland S (1989) Regulated polyadenylation controls mRNA translation during meiotic maturation of mouse oocytes Genes and Development 3 2163-2171
Watson AJ (1992) The cell biology of blastocyst development Molecular Reproduction and Development 33 492-504

Whitten WK and Biggers JD (1968) Complete development in vitro of the preimplantation stages of the mouse in a simple chemically defined medium Joumal of Reproduction and Fertility 17 399-401

Wright RW, Anderson GB, Cupps PT, Drost M and Bradford GE (1976) In vitro culture of embryos from adult and prepubertal ewes Journal of Animal Science $42912-917$ 